\title{
Vitamin D and Fatigue; in a Case with Tuberculosis
}

\author{
D Vitamini ve Yorgunluk; Bir Tüberküloz Olgusunda
}

Buket Mermit Çilingir

\begin{abstract}
Vitamin $D$ is converted into its active metabolites by sunlight. Several illnesses may occur when the serum level of Vitamin D is decreased. The association between tuberculosis and sunlight has been known for hundreds of years, and sunlight was the first method used for the treatment of tuberculosis. Fatigue is often an early complaint of Vitamin D deficiency. We found Vitamin D deficiency in one patient who was initiated on an anti-tuberculosis treatment following a diagnosis of tuberculosis on her persistent complaint of fatigue. The Severity of Fatigue Scale was used to evaluate pre- and post-treatment fatigue scores for Vitamin D therapy, indicating an improvement in the severity of fatigue following the treatment. We believe that the assessment of fatigue, which is usually underestimated by patients and healthcare professionals a like, is probably due to the lack of any attempt to measure it, but would contribute to the evaluation of the treatment response.
\end{abstract}

Key words: Vitamin D, tuberculosis, fatigue.

\section{Özet}

D vitamini aktif metabolitlerine güneş ışığı ile dönüşür. D vitamini serum düzeyinin azaldığı durumlarda çeşitli hastalıklar ortaya çıkabilir. Tüberküloz ile güneş ışığı arasındaki ilişki yüzyıllardır fark edilmiştir ve tüberkülozda kullanılan ilk tedavi yöntemi olmuştur. D vitamini eksikliğinde yorgunluk genellikle ilk şikâyettir. Tüberküloz tanısı ile antitüberküloz tedavi başlanan ancak yorgunluk şikâyeti devam eden hastamızda D vitamini eksikliği tesbit edildi. Yorgunluk Şiddet Skalası, D vitamini tedavisi öncesi ve sonrası hesaplandı ve tedavi sonrası yorgunluk şiddetinin azaldığı görüldü. Hastalar ve hekimler tarafından genellikle gözardı edilen yorgunluk semptomunun ölçülmesinin tedaviye cevabının değerlendirilmesine katkı sağlayacağına inanıyoruz.

Anahtar Sözcükler: D vitamini, tüberküloz, yorgunluk.
Department of Chest Diseases, Van Training and Research Hospital, Van, Turkey
Van Bölge Eğitim ve Araştırma Hastanesi, Göğüs Hastalıkları Kliniği, Van

Submitted (Başvuru tarihi): 09.02.2015 Accepted (Kabul tarihi): 01.04.2015

Correspondence (iletişim): Buket Mermit Çilingir, Department of Chest Diseases, Van Training and Research Hospital, Van, Turkey

e-mail: buketmermitcilingir@gmail.com 
Tuberculosis has a high mortality and morbidity rate. Its incidence varies worldwide according to region. The risk factors include low level of education, lower income, alcohol abuse, lower body mass index, unemployment and a smoking habit. The risk of transmission is higher within the household, particularly in children less than six years of age. The onset and transmission of the disease is facilitated in congregate settings (prisons, care centers, etc.), in the presence of condition leading to lower resistance in the body (HIV infection, malnutrition, use of immunosuppressive agents, and use of TNF alpha inhibitors, etc.) $(1,2)$.

The conversion of 7-dehyrocholesterol into cholecalciferol takes place in the dermis and epidermis on exposure to sunlight. 1,25 $(\mathrm{OH})$ cholecalciferol activates both monocytes and macrophages, both inhibiting the growth of $M$. tuberculosis and switching the immune response from $T$ helper 1 to $T$ helper 2.

Studies have shown that Vitamin D and its metabolites may play a role in regulating granulomatous reactions and they can improve the ability of alveolar macrophages to prevent growth of mycobacteria (3). A low vitamin D level reduces serum total and ionized calcium, ultimately resulting in skeletal demineralization and muscle weakness. Fatigue is the end result of the underlying muscle fatigue, which is more commonly encountered than muscle weakness (4).

\section{CASE}

A 32-year-old female patient presented with complaints of fatigue, shortness of breath, cough and sputum. She reported that her complaints had for the previous few years especially increased in the wintertime but she didn't care, since she attributed it to smoking, and she had smoked for 10 years. However, she decided to take medical advice when for the previous month she had suffered from shortness of breath even during short walks.

The physical examination showed bilateral normal breath sounds by auscultation. A posteroanterior chest $x$-ray showed bilateral multiple scattered opacities in the right lower lung zone and larger ones in the left upper lung zone (Figure 1). The results of blood analysis were as follows: WBC: $7880 / \mathrm{mm}^{3}$; $28 \%$ lymphocyte, erythrocyte sedimentation rate: $2 \mathrm{~mm} /$ hour, CRP: $0.24 \mathrm{mg} / \mathrm{ml}$. ARB was negative in sputum twice. PPD was $12 \mathrm{~mm}$ and BCG scar was positive.

The patient underwent contrasted thoracic CT which showed an irregular consolidation with lobulated contours, measuring $3 \times 0.7 \mathrm{~cm}$ at the widest point with pleu- ral based infiltrate pointed toward the hilar region in the posterior segment of the left upper lobe (Figure 2), multiple nodules, the largest measuring $1.4 \mathrm{~cm}$ in the lateral basal segment of the right lower lobe (Figure 3), and a $1.5 \mathrm{~cm}$ nodular lesion in the posterior basal of the right lower lobe with an air space in the anterior division (Figure 4).

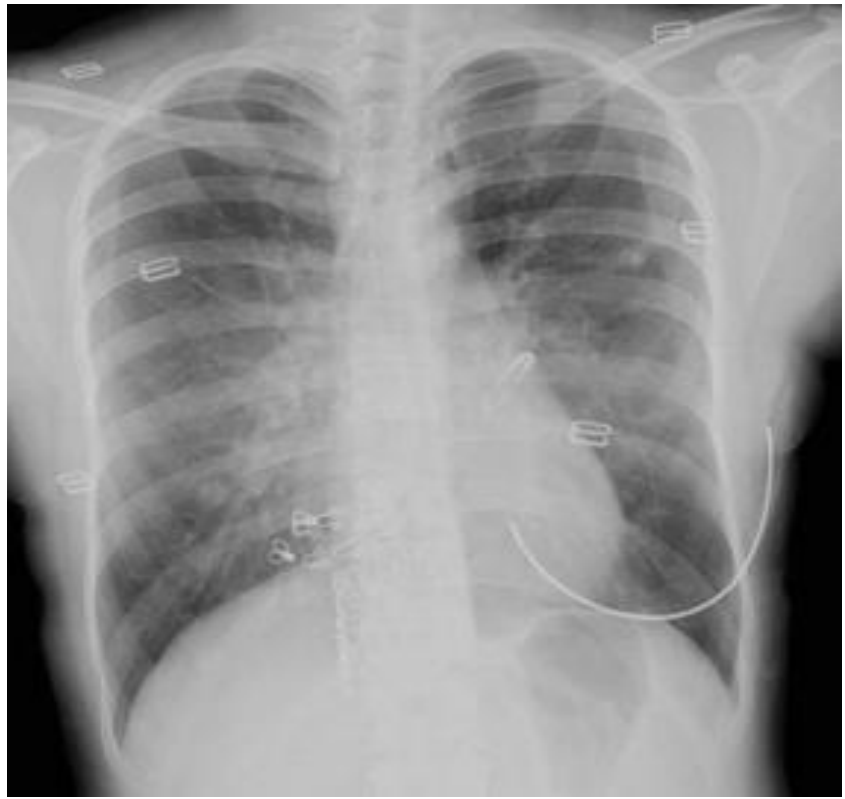

Figure 1: Bilateral multiple scattered opacities in the right lower lung zone and larger in the left upper lung zone

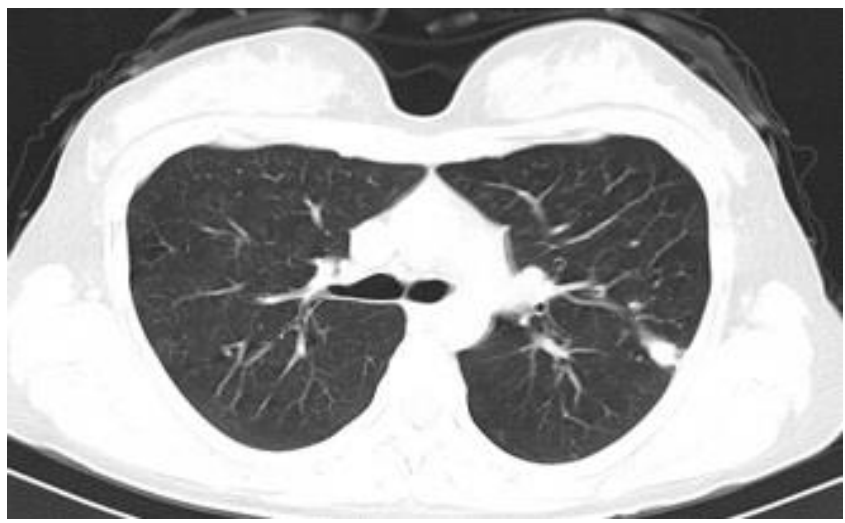

Figure 2: An irregular consolidation with lobulated contours, measuring $3 \times 0.7 \mathrm{~cm}$ at the widest point with pleural-based infiltrate pointed toward the hilar region in the posterior segment of the left upper lobe

The patient was referred to the thoracic surgery department for a thoracoscopic biopsy. The pathology result of the biopsy performed by VATS (video-assisted thoracic surgery) reported granulomatous inflammation with caseification and she was initiated on an anti-tuberculosis treatment and B complex vitamin therapy.

The hemogram and biochemical parameters were normal at the end of the first month of antituberculosis treatment. 
However the patient reported that she still had complaints of fatigue, malaise, joint pain, and shortness of breath on exertion. Therefore, thyroid function tests were performed and levels of Vitamin B12, ferritin, iron and parathyroid hormone were measured, revealing results within the normal range. The level of Vitamin D was $3 \mathrm{ng} / \mathrm{ml}$. The Turkish version of the Fatigue Severity Scale (FSS) was administered to the patient and the FSS score was 24. She started to receive an oral dose of 50,000 IU of Vita$\min \mathrm{D}$. She received it once a week for eight weeks, and the FSS score was reassessed at the end of the treatment, which showed that the score was decreased to 3 . The serum level of Vitamin D was $49 \mathrm{ng} / \mathrm{ml}$ and the patient had no active complaint. The antituberculosis treatment was discontinued at the end of nine months when the thoracic CT showed no increase in the number and size of the nodules.

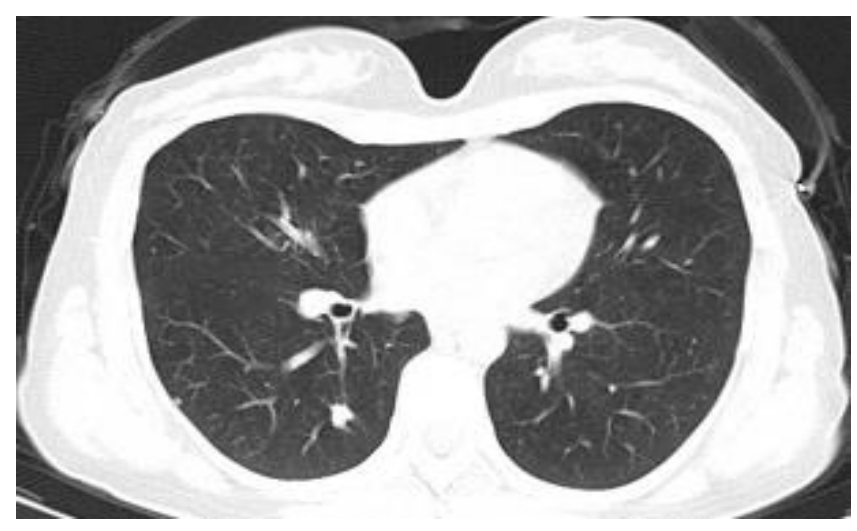

Figure 3: Multiple nodules, the largest measuring $1.4 \mathrm{~cm}$ in the lateral basal segment of the right lower lobe

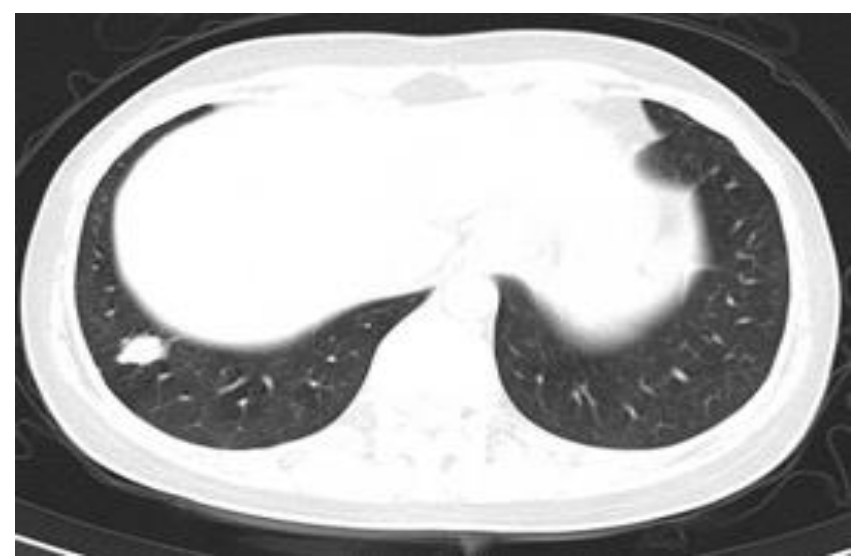

Figure 4: A $1.5 \mathrm{~cm}$ nodular lesion in the posterior basal of the right lower lobe with air space in the anterior division

\section{DISCUSSION}

Turkey is among the countries where tuberculosis represents a severe health problem (2). A study showed an association between lower levels of Vitamin $D$ and tuberculosis.
It stated that there was a summer peak in tuberculosis diagnoses after a midwinter peak in vitamin $D$ deficiency (5).

Vitamin D is essential in calcium homeostasis. It facilitates the absorption of calcium from the intestine, reabsorption of calcium from the kidneys and release of calcium from the skeleton. A low vitamin D level reduces serum total and ionized calcium, resulting in skeletal demineralization and muscle weakness. With better understanding of the formation of Vitamin $D$ and the pathogenesis of tuberculosis, it became clear that Vitamin D was an important mediator of the macrophage activation, which is central to protective immunity against tuberculosis (6). The association between Vitamin $\mathrm{D}$ and tuberculosis has been linked to genetic factors and polymorphism of the Vitamin D receptor (VDR) gene has been implicated (6).

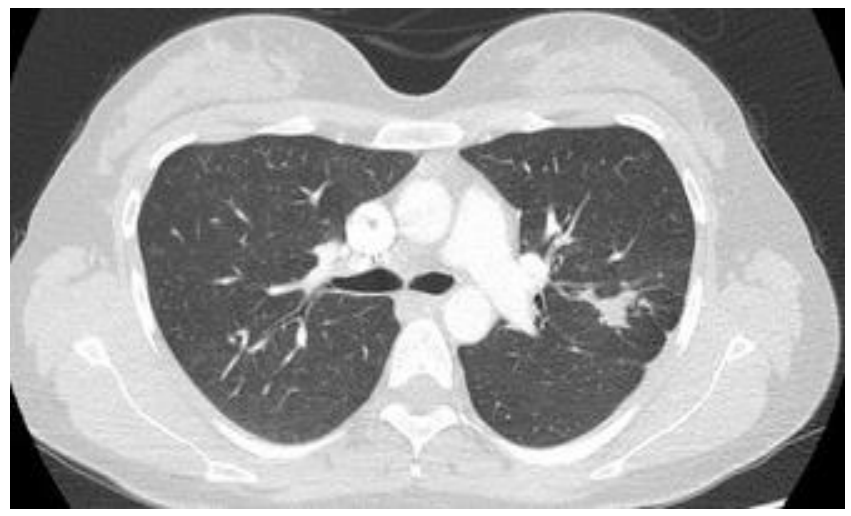

Figure 5: Irregular lobulated consolidation on posterior of left upper lobe after treatment

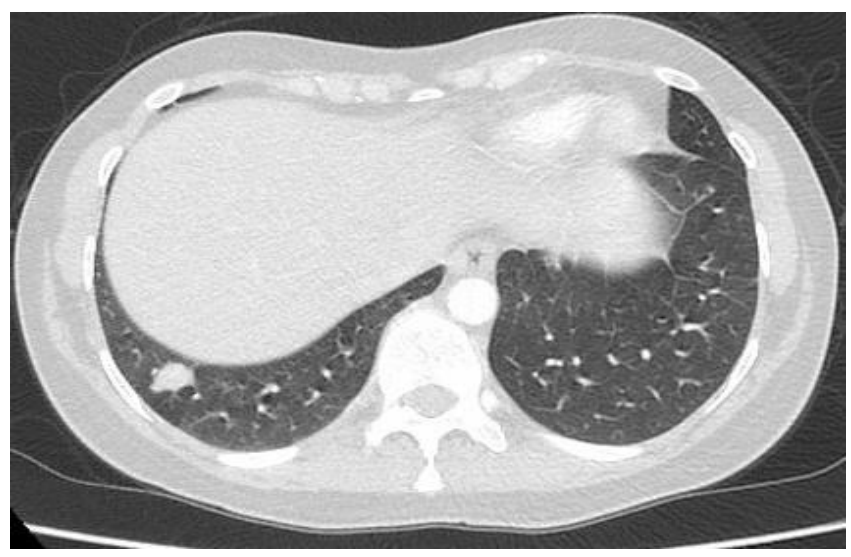

Figure 6: Weakly regressed nodule after treatment on posterobasal of right lower lobe

Mycobacterial ligands bind to the heterodimeric Toll-like receptor $2 / 1$ combination and they activate the Vitamin $D$ receptor and 1- $\alpha$-hydroxylase. The 1- $\alpha$-hydroxylase gene converts the 25-hydroxyvitamin D3, the principle circulating metabolite of Vitamin D to 1,25 dihydroxyvitamin D3 (calcitriol), the bioactive form of vitamin D (5). Calcitriol 
stimulates the expression of the cathelicidin antimicrobial peptide, which can restrict the growth of $M$. tuberculosis (7).

Many studies have been conducted to determine the normal range of $25(\mathrm{OH})$ Vitamin D for identifying the Vitamin D deficiency (8). As result, it was defined as 'deficient' if the $25(\mathrm{OH})$ vitamin D level is less than $20 \mathrm{ng} / \mathrm{ml}$, 'insufficient' if it is between 21 and $29 \mathrm{ng} / \mathrm{ml}$ and 'normal' if it is higher than $30 \mathrm{ng} / \mathrm{ml}$ (3).

In a study designed by Wilkinson et al (9) $25(\mathrm{OH})$ concentrations of Vitamin D were assessed in tuberculosis patients and those contacted them among GujaratiAsians who migrated to the United Kingdom and concentrations less than $10 \mathrm{nmol} / \mathrm{L}$ were considered as insufficiency. The concentrations of Vitamin $D$ were less than this concentration in $67 \%$ of patients and $26 \%$ of TB contacts (9).

In another study which analyzed a group of patients diagnosed with tuberculosis and treated with 10,000 IU/day of vitamin D per day compared to placebo, it was shown that sputum culture negativity was 100\% in the group of Vitamin D versus $77 \%$ in placebo group six weeks after the initiation of antituberculosis treatment (10). In our patient, as the concentration of Vitamin D was at the lowest during the initial assessment and based on the above-mentioned studies, we thought that low levels of Vitamin D might be a contributor to the development of tuberculosis. She received oral dose of 50,000 IU of Vitamin D once a week for 8 weeks, as recommended in the guidelines issued by the Endocrine Society for patients with Vitamin D deficiency, based on the age and underlying medical conditions.

According to these guidelines, all adults who are vitamin $\mathrm{D}$ deficient are recommended to be treated with 6000 $\mathrm{IU} /$ day or 50,000 IU/week of vitamin D2 or vitamin D3 for eight weeks to achieve a blood level of 25(OH)D above $30 \mathrm{ng} / \mathrm{ml}$, followed by a maintenance therapy of 1500-2000 IU/day (1 1).

Fatigue is a subjective experience and the use of patientrated scales is more convenient for the measurement of fatigue (12). The Fatigue Severity Scale is a common tool used for many diseases. We used the Turkish version Fatigue Severity Scale (FSS) to measure the severity of fatigue in our patient (13). The scale consists of nine questions to evaluate the severity of fatigue and each question is rated on a scale ranging from 1 (strongly disagree) to 7 (strongly agree). The higher scores indicate severe fatigue (14).
Our patient had complained of fatigue for a long time. Metabolic disorders that may be associated with fatigue such as thyroid dysfunction, anemia, ferritin, iron deficiency parathyroid hormone dysfunction and low Vitamin B12 levels were investigated, revealing results within the normal range but we found that the concentration of Vitamin D was low. A Vitamin D replacement therapy was planned, but the severity of fatigue was determined using the FSS before treatment. Consequently, we aimed to determine the level of fatigue before and after the treatment. Our aim was also supported by studies, which reported an association between the concentration of Vitamin D and score of fatigue in patients with cancer and myasthenia gravis, and showed an improvement in the Fatigue Severity Scale when the concentration of Vitamin $D$ returned to normal levels $(15,16)$.

In conclusion, since fatigue can both occur in tuberculosis and be one of the side effects of the antituberculosis agents used, it was rational to consider Vitamin D deficiency as an underlying factor for our patient's complaint. Patients and healthcare professionals often underestimate fatigue even though it reduces the quality of life. In other disorders with a concomitant fatigue symptom, assessing the response to treatment using the FSS as an objective measurement of fatigue, will be beneficial.

\section{CONFLICTS OF INTEREST}

None declared.

\section{AUTHOR CONTRIBUTIONS}

Concept - B.M.Ç.v; Planning and Design - B.M.Ç.; Supervision - B.M.Ç.; Funding - B.M.Ç.; Materials - B.M.Ç.; Data Collection and/or Processing - B.M.Ç.; Analysis and/or Interpretation - B.M.Ç.; Literature Review - B.M.Ç.; Writing - B.M.Ç.; Critical Review - B.M.Ç.

\section{YAZAR KATKILARI}

Fikir - B.M.Ç.; Tasarım ve Dizayn - B.M.Ç.; Denetleme B.M.Ç.; Kaynaklar - B.M.Ç.; Malzemeler - B.M.Ç.; Veri Toplama ve/veya İşleme - B.M.Ç.; Analiz ve/veya Yorum - B.M.Ç.; Literatür Taraması - B.M.Ç.; Yazıyı Yazan B.M.Ç.; Eleştirel İnceleme - B.M.Ç.

\section{REFERENCES}

1. Global tuberculosis control: WHO report 2011. Geneva, World Health Organization, 2011 (WHO/HTM/TB/2011.16). 
2. Sağlık Bakanlığı Verem Savaşı Dairesi Başkanlığı. Türkiye'de Verem Savaşı, 2011 Raporu, Fersat Ofset, Ankara 2011.

3. Holick MF. Vitamin D Deficiency. N Engl J Med 2007; 357:266-81. [CrossRef]

4. Brown RH, JR, Amato AA, Mendell JR. Muscular dystrophies and other muscle diseases. In: Fauci AS, Braunwald E, Kasper DL, eds. Harrison's Principles of Internal Medicine. New York: McGraw Hill Medical; 2008:2678-95.

5. Wingfield T, Schumacher SG, Sandhu G, Tovar MA, Zevallos $K$, Baldwin MR, et al. The seasonality of tuberculosis, sunlight, vitamin $D$, and household crowding. J Infect Dis. 2014; 210:774-83. [CrossRef]

6. Liu PT, Stenger S, Li H, Wenzel L, Tan BH, Krutzik S, et al. Toll-like receptor triggering of a vitamin $\mathrm{D}$-mediated human antimicrobial response. Science 2006; 311 :1770-3. [CrossRef]

7. Liu PT, Stenger S, Tang DH, Modlin RL. Cutting edge: vitamin D- mediated human antimicrobial activity against Mycobacterium tuberculosis is dependent on the induction of cathelicidin. J Immunol 2007; 179:2060-3. [CrossRef]

8. Malabanan A, Veronikis IE, Holick MF. Redefining vitamin D insufficiency. Lancet 1998; 351:805-6. [CrossRef]

9. Wilkinson RJ, Llewelyn M, Toossi Z, Patel P, Pasvol G, Lalvani $A$, et al. Influence of vitamin $D$ deficiency and vitamin $D$ receptor polymorphisms on tuberculosis among Gujarati Asian in west London: a case control study. Lancet 2000; 355:618-21. [CrossRef]
10. Nursyam EW, Amin Z, Rumende CM. The effect of vitamin $D$ as supplementary treatment in patients with moderately advanced pulmonary tuberculous lesion. Acta Med Indones 2006; 38:3-5.

11. Holick MF, Binkley NC, Bischoff-Ferrari HA, Gordon CM, Hanley DA, Heaney RP, et al. Evaluation, treatment, and prevention of vitamin $\mathrm{D}$ deficiency: an Endocrine Society clinical practice guideline. J Clin Endocrinol Metab 2011; 96:1911-30. [CrossRef]

12. Comi G, Leocani L, Rossi P, Colombo B. Physiopathology and treatment of fatigue in multiple sclerosis. J Neurol 2001; 248:174-9. [CrossRef]

13. Armutlu K, Korkmaz NC, Keser I, Sumbuloglu V, Akbiyik DI, Guney Z, et al. The validity and reliability of the Fatigue Severity Scale in Turkish multiple sclerosis patients. Int J Rehabil Res 2007; 30:81-5. [CrossRef]

14. Krupp LB, LaRocca NG, Muir-Nash J, Steinberg AD. The fatigue severity scale. Application to patients with multiple sclerosis and systemic lupus erythematosus. Arch Neurol 1989; 46:1121-3.

15. Khan OJ, Reddy PS, Kimler BF, Sharma P, Baxa SE, $\mathrm{O}^{\prime}$ Dea $A P$, et al. Effect of vitamin $D$ supplementation on serum 25-hydroxy vitamin D levels, joint pain, and fatigue in woman starting adjuvant letrozole treatment for breast cancer. Breast Cancer Res Treat 2010; 119:1118. [CrossRef]

16. Askmark H, Haggård L, Nygren I, Punga AR. Vitamin D deficiency in patients with myasthenia gravis and improvement of fatigue after supplementation of vitamin D3: a pilot study. Eur J Neurol 2012; 19:1554-60. [CrossRef] 